\title{
ONLINE LEARNING GUIDELINES FOR ABANDONED CHILDREN AT THE MUHAMADIYAH ORPHANAGE, JALAN NILEM, BANDUNG CITY
}

\author{
Sumardani $^{1}$, Yuyun Yuningsih ${ }^{2}$, Ikhsan Maulana ${ }^{3}$ \\ 1,2,3 Pasundan University, J1. Lengkong 68 Bandung City, Indonesia \\ Sumardani@unpas.ac.idyuyun.yuningsih@unpas.ac.id ikhsanmaulana@unpas.ac.id
}

\begin{abstract}
Today the development of the internet is growing rapidly and has penetrated into several fields, including the field of education. Learning media also developed and gave rise to the Social Learning Network. Zoom meeting is an online learning media that combines several features of the Learning Management System and Social Network into a Social Learning Network specifically created for educational purposes. To obtain an effective learning process, teachers and students must have innovative and interesting learning media, this is what is experienced by the companion/teacher at the Muhammadiyah Orphanage Jalan Nilem. For this reason, researchers from the Social Welfare Study Program, FISIP Unpas, took the initiative to provide online tutoring for abandoned children at the Muhamadiyah Orphanage, Jalan Nilem, Bandung City. This activity was held in the study room of the Muhammadiyah orphanage. The participants of this training are all neglected children who are being cared for by the Muhammadiyah Orphanage on Jalan Nilem, Bandung City. The evaluation of this training is based on the understanding of the facilitators and trainees in each session. In addition, a questionnaire was also given to be filled out by participants to assess the quality of the training at the end of the session.
\end{abstract}

Keywords: Guidance, Online Learning, Abandoned Children

\section{A. Introduction}

The policies taken by various countries affected by the COVID-19 disease, related to the education sector by taking all physical activities off at school, also apply in Indonesia, where all educational activities are closed. This makes the government and related institutions present an alternative educational process for students by teaching distance learning or online learning or learning from home with parental assistance. At the primary, secondary and higher education levels, technically the distance learning process also encountered many obstacles. Students from families who don't have internet access or even don't have cellphones will miss learning when learning 
assignments are delivered via WhatsApp or other applications. In response to such conditions,

The importance of distance learning is not only in the use of technology. Do not let the use of technology only replace the teacher's lectures from the classroom to move places through virtual technology. Many elements are more important in preparing the learning process even at a distance. The main thing is to provide a learning experience that encourages students to experience more (do or observe), interact, communicate, and provide feedback in constructing knowledge so that students can learn meaningfully.(https://edukasi.kompas. com/read/2020/05/31/172306571/.)

The problem of adapting to online learning technology is considered very burdensome for the students who live in the orphanage, because apart from their very limited knowledge and insight into technology, unlike children in general, they are also not equipped with cell phones or computers. Based on information from the caretakers of the orphanage children in carrying out online learning, children/students at the orphanage are given cell phone loans in turn, but the problem is that the supervisor and assistance when accessing their learning lacks guidance from the orphanage due to limited human resources owned by the orphanage. The Muhamadiyah Orphanage is one of those affected by Covid 19, because the majority of the children in this orphanage attend elementary, middle and high school levels. with online learning conditions and being underprivileged children, making it very difficult for the administrators both in guidance, study assistance and procurement of computers or mobile phones to study foster children. Foster children who receive services and social guidance at this orphanage are children belonging to: orphans, orphans, orphans, and children from poor parents. For smooth understanding of online learning delivered by teachers, of course students in terms of These orphans need guidance and assistance.

Based on these conditions, the priority problems that must be addressed are in providing guidance and mentoring on how to learn online and establishing online learning 
independence for children at the Muhamadiyah Orphanage Jalan Nilem Bandung.

\section{Empowerment Concept}

Empowerment is one of the focuses of social work. Empowerment is a process and a goal (Ife, 1995: Suharto, 2010: 82). The meaning of empowerment is as a goal, namely empowerment, in fact it is an indicator of the success of empowerment as a process of their empowerment which involves economic capacity, ability to access social welfare benefits and cultural and political capabilities. The concept of empowerment in the discourse of community development is always associated with the concepts of independence, participation, networking and justice. Basically empowerment is placed on the strength of the individual and social levels. According to Mc Ardle (1989) in (Hikmat, 2013: 3) defines empowerment as a decision-making process by people who consequently carry out these decisions. People who have achieved collective goals are empowered through their independence, even it is a "necessity" to be more empowered through their own efforts and the accumulation of knowledge, skills and other resources in order to achieve their goals without relying on help from external relations. In an effort to empower the community, it can be seen from three sides, namely (Sumodiningrat, 2002); first, creating an atmosphere or climate that allows the community's potential to develop (enabling). Here the starting point is the recognition that every human being, every society, has potential that can be developed. That is, there is no society that is completely without power, because otherwise it would be extinct. Empowerment is an effort to build that power, by encouraging, motivating, and raise awareness of its potential and strive to develop it. Second, strengthening the potential or power of the community (empowering). This strengthening includes concrete steps, and involves providing various inputs (inputs), as well as opening access to various opportunities (opportunities) that will make the community empowered. In empowerment here, where the potential for resources owned by the community is highlighted or strengthened. The existing potential and resources are strengthened so that when the 
community faces problems in their environment, the potential and existing resources in the community will help in solving problems, therefore the existing potential and resources must be explored and strengthened. Third, empowering also means protecting. In the process of empowerment, the weak must be prevented from becoming weaker, because of the lack of power in the face of the strong. Therefore, protection and siding with the weak are very basic in the concept of community empowerment. Community empowerment does not make the community more dependent on various charity programs. Because basically everything that is enjoyed must be produced on their own efforts (the results of which can be practiced with other parties). build the ability to advance themselves towards a better life on an ongoing basis. protection and siding with the weak are very basic in the concept of community empowerment.

Community empowerment does not make the community more dependent on various charity programs. Because basically everything that is enjoyed must be produced on their own efforts (the results of which can be practiced with other parties). build the ability to advance themselves towards a better life on an ongoing basis. protection and siding with the weak are very basic in the concept of community empowerment. Community empowerment does not make the community more dependent on various charity programs. Because basically everything that is enjoyed must be produced on their own efforts (the results of which can be practiced with other parties). build the ability to advance themselves towards a better life on an ongoing basis.

\section{Tutoring Concept}

Tutoring is one of the areas of guidance, to examine the meaning of tutoring, we will first discuss the nature of guidance itself. The definition of guidance according to Crow \& Crow (Prayitno, 2004: 94) is assistance provided by someone, who has an adequate and well-trained personality to individuals of every age to help him manage his own life activities, develop his own view of life, make his own decisions, and bear his own burden. According to Crow \& Crow, the guidance services provided to individuals or groups of individuals 
are useful for avoiding and overcoming problems in their lives independently.

Based on this understanding, it can be concluded that guidance is one form of the process of providing assistance to individuals or groups of individuals in solving problems, so that each individual will be able to optimize their potential and skills in overcoming each problem, and achieve self-adjustment in life.

After understanding the meaning of guidance, the next study presented is one of the areas of guidance, namely tutoring. Tutoring according to Oemar Hamalik (2004: 195) is guidance aimed at students to get an education that suits their needs, talents, interests, abilities and helps students to determine effective and efficient ways to overcome learning problems experienced by students. While the Educational Psychology Department Team (Mulyadi, 2010: 107) said that tutoring is the process of providing assistance to students in solving difficulties related to learning problems.

\section{Online Learning Concept}

The online learning system (in the network) is a learning system without face to face directly between teachers and students but is carried out online using the internet network. Teachers must ensure that teaching and learning activities continue, even though students are at home. The solution is that teachers are required to be able to design learning media as innovations by utilizing online media (online). This is in accordance with the Minister of Education and Culture of the Republic of Indonesia regarding Circular Letter Number 4 of 2020 concerning the Implementation of Educational Policies in the Emergency Period for the Spread of Corona Virus Disease (COVID-19).

The learning system is carried out through a personal computer (PC) or laptop connected to an internet network connection. Teachers can do learning together at the same time using groups on social media such as WhatsApp (WA), telegram, Instagram, zoom applications or other media as learning media. Thus, the teacher can ensure that students take part in learning at the same time, even though in different places.

\section{Abandoned Child Concept}


For the Indonesian people, society, poor families, and children, the economic crisis situation is the beginning of the emergence of various problems that seem increasingly impossible to solve in a short time. A situation like this not only gives birth to a worsening condition of poverty, but also makes the situation very difficult. The crisis at this stage is the most heavily borne by the Indonesian people because it affects the welfare of most of the people. The real welfare of the Indonesian people declined sharply during the crisis and will have an impact on the social conditions of the community. The current situation of economic crisis and urbanization in big cities is increasing, especially in Pekanbaru City. As a result,

Abandoned children are actually children who are categorized as vulnerable children or children who need special protection (children in need of special protection). Vulnerable children themselves are basically a term to describe a group of children who due to situations, conditions, and cultural or structural pressures cause their rights to have not been or are not fulfilled, and their rights are often violated. Judging from the rights of these children, they have rights that must be fulfilled by their parents, namely the right to obtain proper education, self and mental development, express opinions and think, obtain physical and spiritual needs, obtain facilities for playing and recreation and the right to obtain services. adequate health. When the rights of the child are not fulfilled, If there is no attention from their parents, this child can be said to be an abandoned child. A child who does not have both parents or no guardian will be said to be a neglected child, but a child can also be said to be neglected when the rights of the child are not fulfilled fairly or completely.

\section{B. Implementation Method}

The method of implementing community empowerment activities carried out as a solution to the problems experienced by the two partners is online learning guidance for neglected children in Muhammadiyah orphanages, training, mentoring, interactive discussions and practice. The method used was chosen as a problem-solving effort and adapted to the partner's condition.

The approach method used in 
the activity is the social group work method with this technology transfer, namely the provision of materials and demonstrations. The material presented was in the form of the process of making planting media and types of vegetable seeds. Participants listened to the explanation from the speaker, which was followed by a demonstration of making planting media and the types of seeds that could be used.

\section{Result and Discussion}

Implementation and

\section{Implementation of Training}

The implementation of community empowerment activities, in this case the children of the Muhamadiyah Orphanage Jalan Nilem, Bandung City, with activities providing online learning guidance for elementary and junior high school students affected by the civid 19 pandemic, with government policies, all education for all levels is turned into activities study at home using online media. The problem of tutoring at home for children who have parents also faces many obstacles, especially for orphanage children who are mostly orphans, this orphanage becomes a separate problem for the orphanage management, whose human resources are very limited. That's why our empowerment group tries to offer a solution to provide online learning guidance for students in the Muhammadiyah orphanage.

1. Initial Contact

The activity carried out is to review the location of the service, then discuss with partners who will help carry out the service after that. Before starting the activity, it begins with an introduction to the Social Learning Network (SLN) and applications to support online learning such as zoom via the web and mobile. Introductions are used to help participants understand the usefulness of the Social Learning Network (SLN) and in using learning media as a learning process. This training activity took place in the hall of the Muhammadiyah Orphanage, Jalan Nilem, Bandung City and was held on January 18, 2021. Each participant uses 1 computer unit (there are 3 computers available, which are donations from Fisip Unpas), during the practice and given a module/guidebook to facilitate the online learning development process. The activity is carried out in 1 
(one) day with a training duration of \pm 4 (four) hours.

\section{Team Coordination with Partners}

This activity is carried out to equalize perceptions between the service team and partners. This activity is carried out so that it is focused and in accordance with the goals that have been determined and later Through this coordination, it is hoped that the caretakers of the orphanage and the children of the orphanage can utilize and apply information technology as a medium to educate the orphans. So that guidance/assistance and practice at the orphanage are not too burdened with teaching and learning activities and participants can creatively use social network-based learning media. In addition, the caretaker of the orphanage can monitor the teaching and learning process that is not limited to classrooms and school hours. So that the teaching and learning process can also be carried out outside of school hours and areas.

\section{Program Socialization}

The socialization of the program was carried out in the Hall of the Muhammadiyah Orphanage. This socialization activity was attended by the caretaker of the orphanage and the children of the Muhammadiyah Orphanage. In this socialization, the Service Team who was present at the location provided briefing to the caretaker of the orphanage and the children of the Muhammadiyah orphanage, including:

1) 40 minutes of online learning system introduction

2) 180 minutes for a trial run of online learning through the app

3) 20 minutes to evaluate the material that has been delivered

4. Training Implementation

The training was carried out between teams assisted by facilitators from KS Fisip Unpas students who empowered orphanage children, by teaching how to access the internet, activate the internet, access school materials provided by teachers, how to do assignments and how to carry out exams through the media. online. In addition, in the implementation of mentoring and guidance, participants receive material, including:

1) Website-based online learning materials, taking notes, sharing materials, assignments and assessments are then evaluated. 
2) Mobile-based online learning materials, taking notes, sharing materials, assignments and assessments are then evaluated

5. Accompaniment

After students can use online learning media, because orphanage children have different abilities, mentoring is carried out until they are independent in carrying out the online learning process using computers, cellphones and laptops. In this assistance the orphanage administrators and practitioners continue to monitor the development of each child how the orphanage child can use online learning media to complement their daily learning needs. It is expected that the children's ability to use learning media with distance learning applications through the website or mobile application is expected.

\section{Termination}

The final stage is carried out to provide all facilities as a sign that empowerment has been completed.

\section{Conclusion}

The caretaker of the orphanage and the children of the Muhammadiyah Orphanage on Jalan
Nilem, Bandung City as beneficiaries after receiving guidance on the use of online learning media Social Learning Network (SLN) by using an application on a laptop or cellphone. The administrators of the orphanage and the children of the orphanage know the benefits of online learning applications in the teaching and learning process and can use the features provided as learning media that are not confined to the classroom and effective school time. Orphanage children can use information technology as a medium to educate students and are not too burdened with teaching and learning activities and students can creatively use learning media as a supporter of the teaching and learning process.

\section{Suggestion}

There needs to be a change in teaching patterns from the teaching and learning process which is only done in schools to the use of information technology so that coaches and students can still carry out the teaching and learning process after the effective school hours are over. In addition, assistance is needed when introducing online learning media to children to make it easier to 
understand and orphanage children can be introduced to information technology that is beneficial for education.

\section{BIBLIOGRAPHY}

Adzharuddin, Nor Azura and Ling, Nor Azura., 2013, Learning Management System (LMS) among University Students: Does It Work?, International Journal of e-Education, e-Business, eManagement and e-Learning, Vol.

$$
\text { 3, No. } 3
$$

Boyd, DM \& Ellison, N. B, 2008,

Social network sites: definition, history, and scholarship, Journal of Computer-Mediated

Communication, 13, 1, 210-230

Bagong Suyanto, Child Social

Problems, (Jakarta: Kencana, 2010), p. 3. 2 Agus Dwiyanto et al,
Huang, JJS, Yang, SJH, Huang, Y.M., and Hsiao, IY T, 2010, SocialLearning Networks: Build Mobile Learning Networks Based on Collaborative Services, Educational Technology \& Society, 13 (3), 78-92.

Kurniawan, Rendra., 2009, Analysis and Design of Web-Based ELearning Applications, Adhi Tama Institute of Technology, Surabaya-Indonesia

Poverty and Regional Autonomy, (Jakarta: LIPI Press, 2005), p. 6163.

Wang, Qiyun., Woo, Huay Lit., Quek, Choon Lang., Yang, Yuqin and Liu, Mei., 2012, Using the Facebook group as a learning management system: An exploratory study, British Journal of Educational Technology Vol 43 No 3. 